\title{
From Lithological Modelling to Groundwater Modelling: A Case Study in the Tiber River Alluvial Valley
}

\author{
Cristina Di Salvo ${ }^{1^{*}}$, Marco Mancini ${ }^{{ }^{*}}$, Massimiliano Moscatelli ${ }^{1}$, Maurizio Simionato ${ }^{1}$, Gian Paolo Cavinato ${ }^{1}$, Michele \\ Dimasi $^{2}$ and Francesco Stigliano ${ }^{1}$
}

1 CNR- Institute of Environmental Geology and Geoengineering; cristina.disalvo@igag.cnr.it; marco.mancini@igag.cnr.it; massimiliano.moscatelli@igag.cnr.it; maurizio.simionato@igag.cnr.it; gianpaolo.cavinato@igag.cnr.it; Francesco.stigliano@igag.cnr.it

2 Freelance geologist; michele.dimasi2004@libero.it

* Correspondence: C.D.S., cristina.disalvo@igag.cnr.it; M.M., marco.mancini@igag.cnr.it

\begin{abstract}
This study presents the results of a research project financed by the Lazio Regional Government. The research focused on defining an integrated model of recent alluvial deposits in the Tiber River. To achieve this objective, geological boreholes were made to monitor the aquifer and in situ and laboratory tests carried out. The data obtained was used to detail stratigraphic aspects and improve the comprehension of water circulation beneath the recent alluvial deposits of the Tiber River in the urban area of Rome, between the Ponte Milvio bridge and the Tiber Island. The stratigraphic intervals recognised in the boreholes were parameterised based on their litho-technical characteristics. The new data acquired, and integrated with existing data in the CNR IGAG database, made it possible to produce a three-dimensional model of the lithologies in the study area.The model of the subsoil, simplified for applied reasons, was described in hydrostratigraphic terms: three different lithotypes were subjected to piezometric levels monitoring. Finally, the research generated a numerical hydrological level in a stationary regime. In general, this study demonstrates how a numerical hydrogeological model calibrated by piezometric monitoring data can support the construction of a geological model, discarding or confirming certain hypotheses and suggesting other means of reconstructing sedimentary bodies.
\end{abstract}

Keywords: 3D geological modelling, groundwater models, incised valleys, Rome, alluvium

\section{Introduction}

This article describes the results of the activities defined in the research contract between the Istituto di Geologia Ambientale e Geoingegneria del Consiglio Nazionale delle Ricerche (IGAG-CNR) and Geoplanning-Servizi per il Territorio as part of the project "TIBER - Innovazione nel campo geotecnico per la definizione di strumenti, metodologie operative e procedure finalizzate alla realizzazione di un nuovo modello di sottosuolo (modello integrato)", financed by the Lazio Regional Government. Additionally, it also presents the results obtained by a study successive to completion of the contract.

The objective of the research contract was the creation of a geological model and a three-dimensional model of recent alluvial deposits in the Tiber River in the urban area of Rome between the Ponte Milvio bridge and the Tiber Island. The models were utilised to improve the understanding of the circulation of underground water. For this purpose, geological drillholes and in situ boreholes were carried out, as well as laboratory tests and piezometric monitoring in two wells. This was followed by a study of the stratigraphic 
levels recognised in the boreholes, which were parameterised based on their lithotechnical characteristics. The subsoil model, simplified for applied purposes, was then described in hydrostratigraphic terms, and a monitoring of the piezometric levels was applied in three different lithotypes. Finally, the results of the activities carried out under the contract were successively utilised to produce a three-dimensional numerical hydrogeological model in a stationary regime. The model was created to verify the conceptual hydrostratigraphic model, analysing the spatial distribution of lithotypes in relation to the measured piezometric levels, and thus providing the base for a transitory numerical hydrogeological model, at the scale of the site.

The study area constitutes an unusual zone in hydrogeological terms, as it represents an alluvial valley incised into the low permeability clays of the Vatican Hill. Owing to this characteristic the alluvial aquifer-river system is not influenced by external factors, making it possible to study in detail the behaviour of alluvial sediments from perturbations such as flood waves.

\section{Geological and Hydrogeological Setting}

\subsection{Geology and Stratigraphic Sequences}

The study area includes a portion of the alluvial valley of the Tiber River in the urban area of Rome. The Tiber has the second largest hydrographic basin of any river in Italy $\left(17,000 \mathrm{~km}^{2}\right)$. Its relative hydrographic system began to develop during the late upper Pliocene-lower Pleistocene ([1]; [2] and reference therein). The lower course of the Tiber is situated in the Roman Basin, an extensive tectonic-sedimentary basin from the Pliocenequaternary era, where a relevant part of the sedimentary fill consists, since the late lower Pliocene (approx. 1.1 My), by a complex stacking of incised valleys filled with fluvial and coastal sediment and interfluvial deposits ([3, 4]; [5]). In the Roman Basin the Tiber system has witnessed fluvial responses to the concomitant actions of factors of external control, such as glacial-eustatic oscillations in sea level, volcanic activity in the neighbouring Volcanic Districts of the Sabatini Mountains and Alban Hills, sediment discharge from upstream sectors of the hydrographic basin and regional lifting and the final phases of extensional tectonic involving the Tyrrhenian edge of the Apennines (figure 1).

With regard to these factors of external control, among the glacial-eustatic oscillations in sea level the most significant in the Roman Basin, in terms of the preservation of associated sedimentary deposits and the architecture of deposits, is that relative to the last interglacial and glacial phase up to the recent sea level rise. of the upper Pleistocene-Holocene (the last $116 \mathrm{ky}$ ). The sedimentary expression of this depositional cycle controlled by eustatism is represented by the Depositional Sequence of the Tiber River (TDS in [4]), a sequence with a high frequency and low range delimited by a clear surface of non-conformities (SB sequence boundary) characterised in general by a U-shape, transversal to the axis of the valley.

In the urban section of the Tiber, the TDS includes the incised Tiber valley. The latter is deeply set info the Plio-Pleistocene substrate and filled with alluvial deposits, often up to a maximum of 60-70 $\mathrm{m}$ and deposited by the river in large part through mechanisms of backfilling ([6]) in response to the rising and high stand of the sea level. The ratio width/thickness of the filling (W/T ratio in [7]) is between 25 and 40 ([8]). The fill deposits present a level-horizontal position. The stratigraphic architecture of the incised valley fill was reconstructed through an examination and corelation of approximately 900 boreholes ([4]). The relative stratigraphic descriptions are archived in the CNR-IGAG database, and the original data was provided largely by public entities and private companies. The stratigraphy of the boreholes was utilised to produce several corelation drawings (figure 4). These drawings were created to: 1 ) define the form of the valley and the limit of the Tiber River sequence at its base; 2) recognise the principal lithostratigraphic-sedimentologic components of the valley fill (channelized bodies, floodplain, levee and crevasse splay deposits, organic and peaty layers, etc.); 3) identify the significant internal surfaces of the 
stratigraphic sequence (maximum flooding surface, first transgressive surface) essential for corelating the fluvial deposits within the sequence with coastal, deltaic and estuarine deposits. Additionally, three new boreholes (S1, S2, S3, figure 2) were drilled in the framework of the research project through the entire sequence as far as the base surfaces.

A detailed analysis of the facies was made of these boreholes, keeping to the specific recommendations provided in literature on alluvial and channel deposits ([9]; [10]). The results are presented in detail in [4]. Stratigraphic surfaces of particular significance in terms of corelation were identified within the valley fill. They include the sequence boundary (SB), the first transgressive surface (ts), and the maximum flooding surface (mfs) (figures 2 and 4). These surfaces identify substantial changes to the general configuration of the facies in the various depositional environments in relation to the variations between the space of accommodation and the sedimentation rate. While in coastal zones the aforementioned surfaces are strictly corelated to variations in sea level, which directly control accommodation (together with the subsidence of the seabed), in the innermost fluvial areas these surfaces are linked to both the response of the fluvial system to sea level variations and to other control factors, such as the hydraulics of the system, the compaction of alluvial terrains, tectonics, climate and the sedimentary supply ([6]; [11]; [12]; [13]; [14]; [7]; [15]). These surfaces of stratigraphic corelation made it possible to vertically subdivide the alluvial terrains into three portions with a stratigraphic continuity: systems tracts, laterally continuous to those recognised in the deltaic sector of the Tiber Sequence $([16,4])$. The oldest deposits in the sequence correspond with the early lowstand systems tract (ELST), rare remnants of terraced sediments, deposited in a fluvial environment during the lengthy phase of lowering of the base level (between approx. 116 and $26 \mathrm{ky}$ ). These terraces, up to $20 \mathrm{~m}$ thick, consist of a fining-upward succession of gravels and sands that become clays and overconsolidated silts. The terraces were then buried by much more recent transgressive deposits, detached with respect to the base deposits of the sequence (and thus not in stratigraphic continuity), corresponding with the late lowstand systems tract (LST). The lower portion of the sequence, corresponding with the late lowstand systems tract (LST, between 26 and $14 \mathrm{ky}$ ), is recorded between the sequence boundary SB and the first transgressive surface $\mathrm{ts}$, and between 8-10 m thick. This portion of the sequence is associated with amalgamate gravely deposits, not always preserved at the bottom of the incised valley (see also [4]). The gravels consist of well-rounded stones with a maximum diameter of $8 \mathrm{~cm}$, formed of limestone, flint and more rarely of sandstone and pyroclastics. The matrix consists of coarse sands rich in ferromagnesian minerals.

The intermediate portion of the sequence, corresponding with the transgressive systems tract (TST), is up to $40 \mathrm{~m}$ thick and located between the transgressive surface ts and the maximum flooding surface $\mathrm{mfs}$, both with a planar geometry. The base of the TST consists of gravels fining-upward into medium-coarse sands, with a maximum thickness of $10 \mathrm{~m}$, attributed to a gravelly-sandy braided fluvial environment. To the sides are overconsolidated and pedogenically modified well-drained floodplain clayey deposits. The sands define the filing of fluvial channelized bodies, up to 6-8 $\mathrm{m}$ thick and $200 \mathrm{~m}$ wide, with a vertical fining-upward of the lithofacies from medium-coarse sands to granules to fine silty sands. The channelized bodies are attributed to a meandering fluvial environment and laterally bounded by largely unconsolidated grey clays rich in organic material, typical of a poorly drained floodplain. The clays are often interspersed at decimetric levels by backswamp peats. The upper portion of the sequence is $20 \mathrm{~m}$ thick and positioned between the mfs and the current topographic surface, corresponding with the highstand systems tract (HST). In this portion of the sequence, the sandy channelized bodies tend to expand laterally to $600 \mathrm{~m}$, as a consequence of the reduction in the space of accommodation and channel clustering, while the (well drained) floodplain deposits consist of overconsolidated and highly pedogenised silts and clays.

The definition of the lithofacies within the HST and their spatial variability derive principally from the analyses and correlation of well data. This was accompanied by the mapping of the lithofacies at various depths, which permits the identification in plan of the principal associated paleo-geographic elements and environments (such as active 
braided channel areas, or channel belt areas or active channel-levee, drained and undrained floodplain) and to reconstruct their areal distribution.

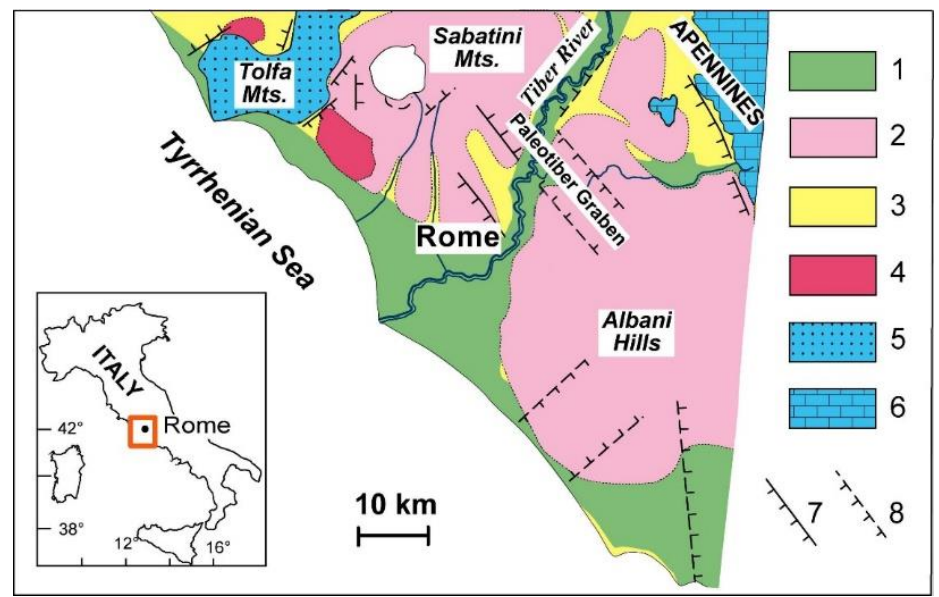

Figure 1. Geological setting of the study area and related depositional sequences. 1.Fluvial, coastal and shallow marine deposits; 2 . Middle Pleistocene volcanites; 3 . Coastal and shallow marine deposits; 4. Upper Pliocene volcanites; 5. Silicoclastic successions (Cretaceous-Eocene); 6. Carbonate successions (Trias-Miocene).

\subsection{Boreholes analyses and correlation}

In terms of lithofacies, boreholes S1, S2, and S3 (see table 1 for details) are representative of limey-clayey and sandy channel deposits. In particular, boreholes S1 and S3 present limey-clayey terrains belonging to the floodplain facies (with channel sands and gravels at the base), while borehole S2 is representative of sandy channel deposits (Figure 2).

Table 1. Coordinates (UTM WGS84, 33N), elevation and depth of drilled boreholes. The distance between the wells and the riverbank was calculated orthogonally to the axis of the river. The distance between the well and the mouth of the river, along both the median of the alluvial valley and the river channel was also calculated.

\begin{tabular}{cccccccc}
\hline Borehole & $\begin{array}{c}\text { X (UTM } \\
\text { WGS84) }\end{array}$ & $\begin{array}{c}\text { Y (UTM } \\
\text { WGS84) }\end{array}$ & $\begin{array}{c}\text { Elevation } \\
\text { (m a.s.1.) }\end{array}$ & Depth & $\begin{array}{c}\text { Borehole distance } \\
\text { from the riverbank } \\
(\mathrm{km})\end{array}$ & $\begin{array}{c}\text { River mouth distance } \\
\text { along the alluvial } \\
\text { valley }(\mathrm{km})\end{array}$ & $\begin{array}{c}\text { River mouth } \\
\text { distance along } \\
\text { the river }(\mathrm{km})\end{array}$ \\
\hline S1 & 288892.34 & 4643538.26 & 17.0 & 59 & 1.225 & 29.29 & 41.45 \\
S2 & 289991.13 & 4642103.57 & 18.2 & 53.5 & 0.066 & 29.00 & 39.37 \\
S3 & 289265.5 & 4643739.93 & 17.6 & 65 & 0.987 & 31.00 & 41.2 \\
\hline
\end{tabular}

For each borehole's core, sedimentological, mineralogical and chemical analyses were made by extracting samples every $20 \mathrm{~cm}$ of perforation. The samples were tested to date and to define a set of physical parameters such as granulometry and mineral composition, and to establish dates for the age of the sample. In particular, the following tests were made:

- $\quad$ sedimentological (granulometric laser analyses)

- mineralogical (diffractometric analyses)

- chemical (definition of the content of water and crystallisation up to $200^{\circ} \mathrm{C}$, content of oxidisable organic matter up to $600^{\circ} \mathrm{C}$, inorganic carbonates up to $850^{\circ} \mathrm{C}$ )

- micropaleontological (calculation of the fossiliferous content of the lithotypes)

- radiometric (C14 dating of organic matter). 
Based on the results obtained, the fossils and sedimentary structures present it was possible to reconstruct the environment of sedimentation of the diverse lithotypes.
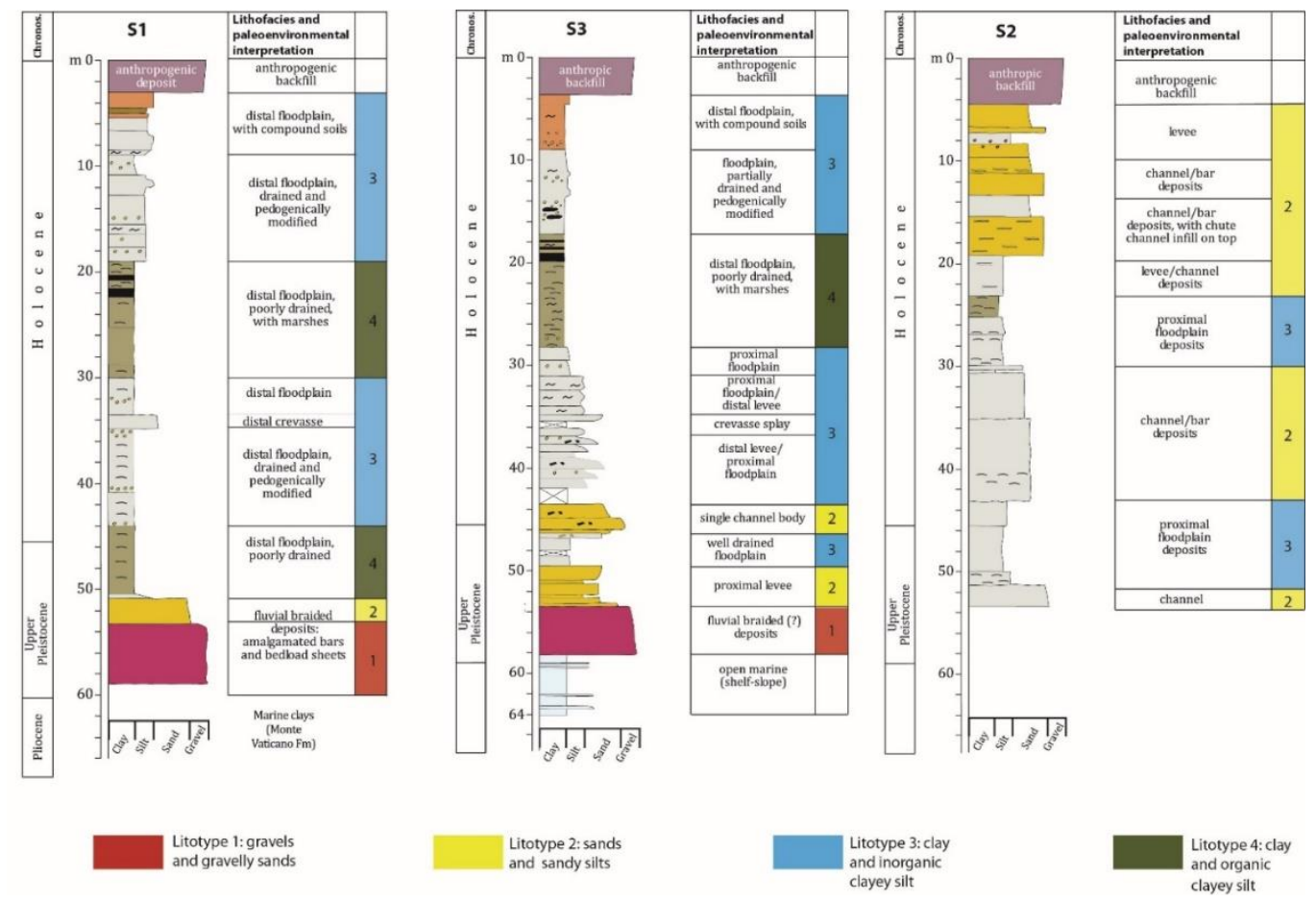

Figure 2. Stratigraphic-sedimentologic logs of boreholes S1, S2, and S3 (after [8]).

Table 2 illustrates the correlation between the associations of lithofacies, the depositional environments and the reference lithotypes for the integrated model of the subsoil. In particular, the lithotypes are lithologic units for the geotechnical and hydrogeological characterisation of the subsoil and identified by combining the associations of lithofacies with similar granulometric-textural features. There is also a good correspondence among the lithotypes, always clearly identifiable from an attentive reading of the descriptions of the borehole data, and the depositional environments, defined by the associations of lithofacies based principally on sedimentary and pedogenic processes. The stratigraphic correlation between lithologies and lithotypes carried out using the borehole tests within the framework defined in table 2 made it possible to provide very restrictive stratigraphic and sedimentologic limits for the corelation between tests, for the reconstruction of the phases that filled the valley and the calculation of the aggradation rates. The cross sections of figure 3 illustrate the stratigraphic architecture of the valley fill.

Table 2. Comparison between associations of lithofacies, depositional environments and reference lithotypes for the integrated model.

\begin{tabular}{|c|c|c|}
\hline Associations of Lithofacies & $\begin{array}{l}\text { Depositional } \\
\text { Environments }\end{array}$ & Lithotypes \\
\hline $\begin{array}{l}\text { Active channel, gravels and fluvial sands } \\
\text { (Gs) }\end{array}$ & $\begin{array}{l}\text { Gravel bed braided } \\
\text { river }\end{array}$ & Gravels, with gravelly sands \\
\hline $\begin{array}{l}\text { Active channel, medium-fine sized sands } \\
\text { and silts (Smf); crevasse splay, fine-sized } \\
\text { sands and silts (Scr); abandoned channel, }\end{array}$ & Channel belt & $\begin{array}{l}\text { Sands and sandy silts (the lithotype in question also } \\
\text { includes deposits not strictly linked to the channel-bank } \\
\text { system, but also the sandy-silty deposits of overbanks }\end{array}$ \\
\hline
\end{tabular}




\begin{tabular}{|c|c|c|}
\hline $\begin{array}{l}\text { fine-sized sands, silts and clays (Sch); levee, } \\
\text { heterolithic alternations of sands and muds } \\
\text { (Sp) }\end{array}$ & & $\begin{array}{l}\text { linked to the crevasse splays, however, in general } \\
\text { adjacent to the original channel belt) }\end{array}$ \\
\hline Drained floodplain muds (Dp). & $\begin{array}{l}\text { Well drained } \\
\text { floodplain }\end{array}$ & Clays and inorganic clayey silts \\
\hline Undrained floodplain muds (Dp). & $\begin{array}{l}\text { Undrained floodplain; } \\
\text { marsh; peat fen }\end{array}$ & Clays and organic clayey silts \\
\hline $\begin{array}{l}\text { Facies belonging to formations previous to } \\
\text { the most recent climatic cycle }\end{array}$ & Geological substrate & Marly clays, sands, gravels, pyroclastics. \\
\hline
\end{tabular}

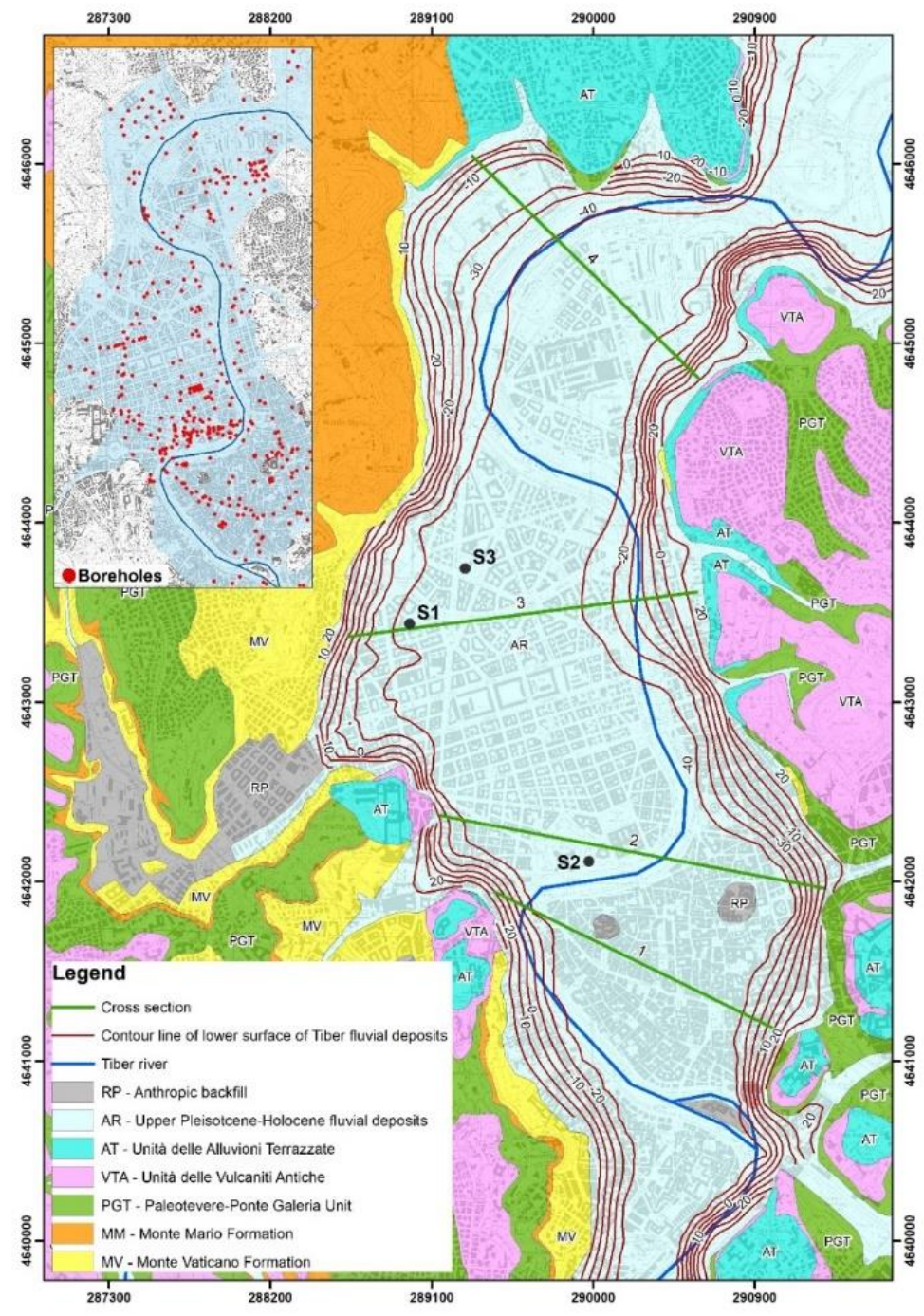

Figure 3a. Geological map of the study area, location of S1-S2-S3 boreholes, and trace of cross sections of Fig. $3 b$ and 3c. The basal surface of Tiber River depositional sequence is also mapped (contour lines every 10 meters). 

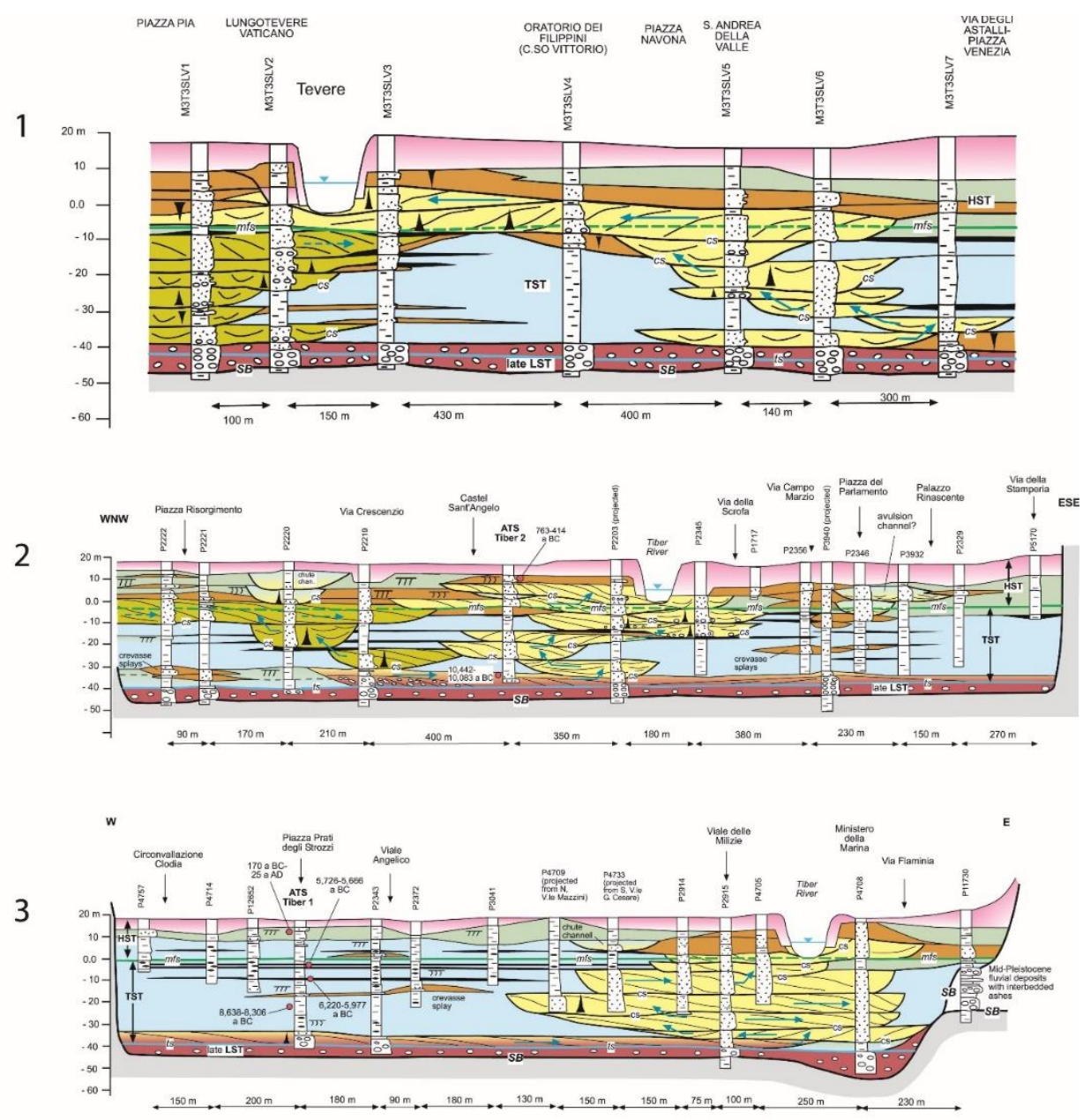

Figure 3b. Cross sections 1-3 through the Tiber River depositional sequence (after [5]). 1: Piazza PiaPiazza Venezia. 2: Piazza Risorgimento-Fontana di Trevi. 3: Prati-Flaminio. Traces in figure 3a; legend in figure $3 \mathrm{c}$. 


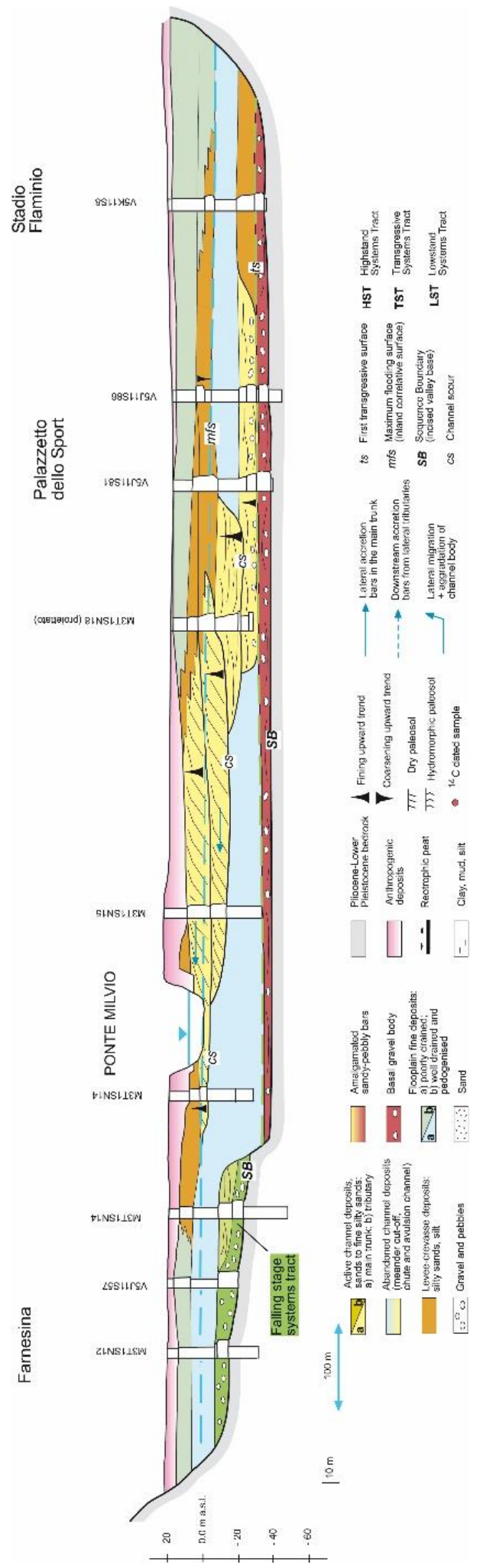

Figure 3c. Cross section 4 through the Tiber River depositional sequence: Farnesina-Stadio Flaminio. Traces in figure $3 \mathrm{a}$. 


\subsection{General Hydrogeological Setting}

In the area of Rome underground flow is directed by high piezometries, located on the slopes of the Sabatini Hills and Alban Hills, toward the Tiber valley, which crosses the city in the NE-SW direction (figure 4); the underground waters run initially within the volcanic and pre-volcanic sedimentary units, before flowing into the alluvial terrains of the Tiber valley and being drained toward the Tyrrhenian Sea.

The most superficial aquifer is hosted in the volcanic formations and the uppermost part of the sedimentary succession of the "Ponte Galeria" Unit ([17]; [18]; [19]), corresponding with the Santa Cecilia Unit ([20]). The remaining portion of the Ponte Galeria Unit in turn presents more overlapping aquifers, consisting of sandy-gravely layers bounded by clayey interlayers. Overall, circulation is supported at the base by the impermeable clays of the Monte Vaticano formation ([21], [17], [19], [22]).

The Tiber valley thus constitutes the receiving hydrogeological unit for subterranean waters. It is characterised by different depositional facies that determine a notable heterogeneity in values of permeability (table 3 ).

The elevation of the water table at the edges of the valley varies between 15 and 10 metres (decreasing from north to south) and presents a low hydraulic gradient ( $\mathrm{i}=0.002$ measured in the historical centre, $[23,24])$. The recharging of the Tiber valley aquifer is a result of stratigraphic contact with the units into which the valley is incised. The greatest hydraulic transfer is hypothesised where the fluvial valley is incised into the sedimentary deposits of the Ponte Galeria Unit. On the contrary, where the valley is incised into the low permeability sediments of the Monte Vaticano and Monte Mario Clays, the hydraulic transfer can be considered negligible. The elevation of the water table is strongly influenced by the level of the Tiber River; under normal flow conditions, the Tiber acts primarily as a receiver from the aquifer (i.e., acts as a gaining stream); under flood conditions, the Tiber feeds the aquifer (i.e., acts as a losing stream).

\section{Description of Hydrogeological Complexes:}

This section describes the principal hydrogeological complexes in Rome according to the classification provided in [25] (figure 4). Table 3 lists the values of hydraulic conductivity.

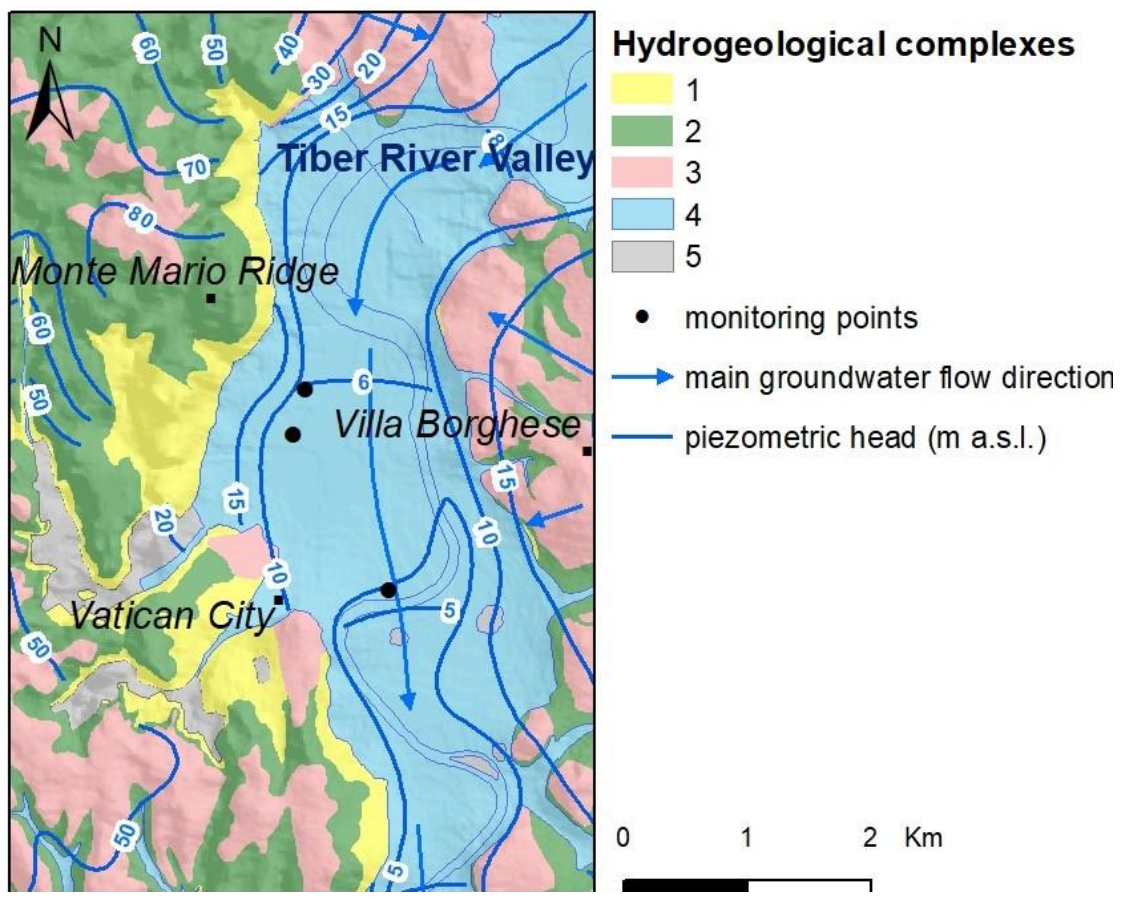


Figure 4. Hydrogeological complexes in the study area. The boreholes S2 and S3 are the equipped with piezometers for groundwater monitoring.

Complex 1: includes the marine clays of the Monte Vaticano Unit and the lower part of the Monte Mario Unit (the so-called "Membro di Farneto" in [2]) from the lower Pliocene-Pleistocene. Its permeability is very low $(0.001-0.0001 \mathrm{~m} / \mathrm{d})$; the complex has an aquiclude function for the study area.

Complex 2: corresponds with the fluvial-deltaic and alluvial sequence of the Ponte Galeria Unit of the mid-lower Pleistocene. It also includes the upper part of the Monte Mario Unit. This complex is characterised by a notable lithologic heterogeneity; the range of permeability is between 0.01 and $0.14 \mathrm{~m} / \mathrm{d}$. Where it is covered by a variable thickness of volcanic deposits, it may host neighbouring aquifers.

Complex 3: includes all the volcanic deposits and sedimentary sin-volcanic units of the Mid-Upper Pleistocene, and presents highly variable values of permeability (from 0.1 up to $6 \mathrm{~m} / \mathrm{d}$ ). The highest values of permeability are characteristic of non-lithified pyroclastic deposits and highly fissured tuffaceous rock formations: both of these lithologies host the most superficial, phreatic aquifer. This complex covers practically the entire urban area, with the exception of the Monte Mario chain and the alluvial valleys of the Tiber and Aniene rivers.

Complex 4: includes the deposits that fill the Tiber valley and its tributaries, datable to the upper Pleistocene-Holocene. They consist of silty clays and silty-sandy deposits, atop a base level of sandy and silty gravels. Internally it features 4 distinct sub-complexes, corresponding with different depositional environments: coarse sediments (high permeability) are related to a high energy sedimentary regime, while silty-clayey sediments are connected with low energy environments such as floodplains or fluvial-palustrine environments.

Complex $4 a$ : is the most superficial unit, characterised by clays and silty clays.

Complex $4 b$ : consists of fine and coarse sands, often with a silty matrix. The sands, deposited in a fluvial channel environment, are surrounded by the clays of complex $4 \mathrm{a}$.

Complex $4 c$ : consists of grey clays with organic matter.

Complex $4 d$ : this sub-complex consists of a discontinuous bed of silty-sandy gravels varying between 0 and 30 metres in thickness. This deposit is related to high energy fluvial environments and characterised by highly variable values of hydraulic conductivity (0.03$6.5 \mathrm{~m} / \mathrm{d}$ ), which depend on the matrix of the deposit.

Complex 5: The urban territory is covered by a practically continuous cover of backfill. Given its average values of permeability $(0.1-0.01 \mathrm{~m} / \mathrm{d})$, this deposit can function as an aquifer when it reaches significant thicknesses (as in the historical centre, where it surpasses 15 metres).

Table 1. Hydrogeological parameterisation of the complexes (from [25]). 


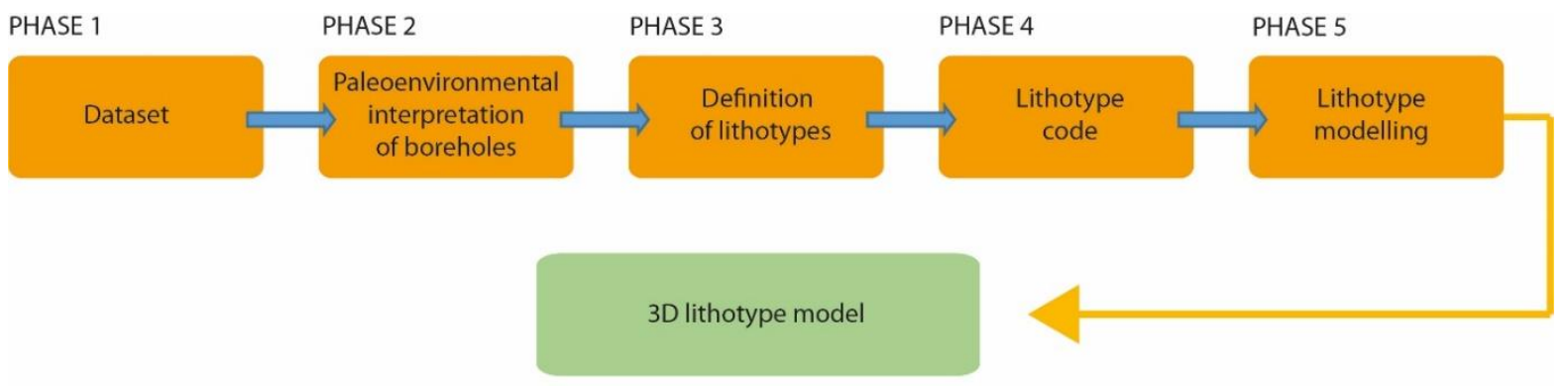

Figure 5: Workflow showing the phases of the 3D lithotype model development.

Hence, from the spatial distribution of the lithofacies it is possible to visualise also the distribution of the lithotypes with their associated physical-mechanical parameters. In other words, this is a manner for representing and visualising the lithological domains with homogenous physical and mechanical characteristics. The reconstruction of the geometries of these lithological bodies becomes a fundamental base geological element for diverse applied questions which may present themselves in urban areas (settlement, variations in permeability etc.).

Beginning with this process it was possible to create a three-dimensional model of the lithotypes recognised in the Tiber valley, in the sector between the Ponte Milvio bridge to the north and the Tiber Island to the south.

The creation of the 3D model was carried out with the methodology described in the following sections.

\section{Codification of Each Stratigraphic Interval Traversed by Boreholes and Recog- nised Lithotypes}

The first step toward the realisation of the three-dimensional model of the recent alluvial deposits was the codification of the boreholes, by means of the lithotypes defined in Table 2 and the stratigraphic framework of Figure 6. The three-dimensional modelling software utilised (RockWorks 15, RockWare ${ }^{\circledR}$ ) requires the definition of numerical values to interpolate the diverse lithologies in the model (Table 4). Thus, it was necessary to define numerical codes for the lithologies present, used to codify the diverse stratigraphic horizons encountered by the boreholes. 


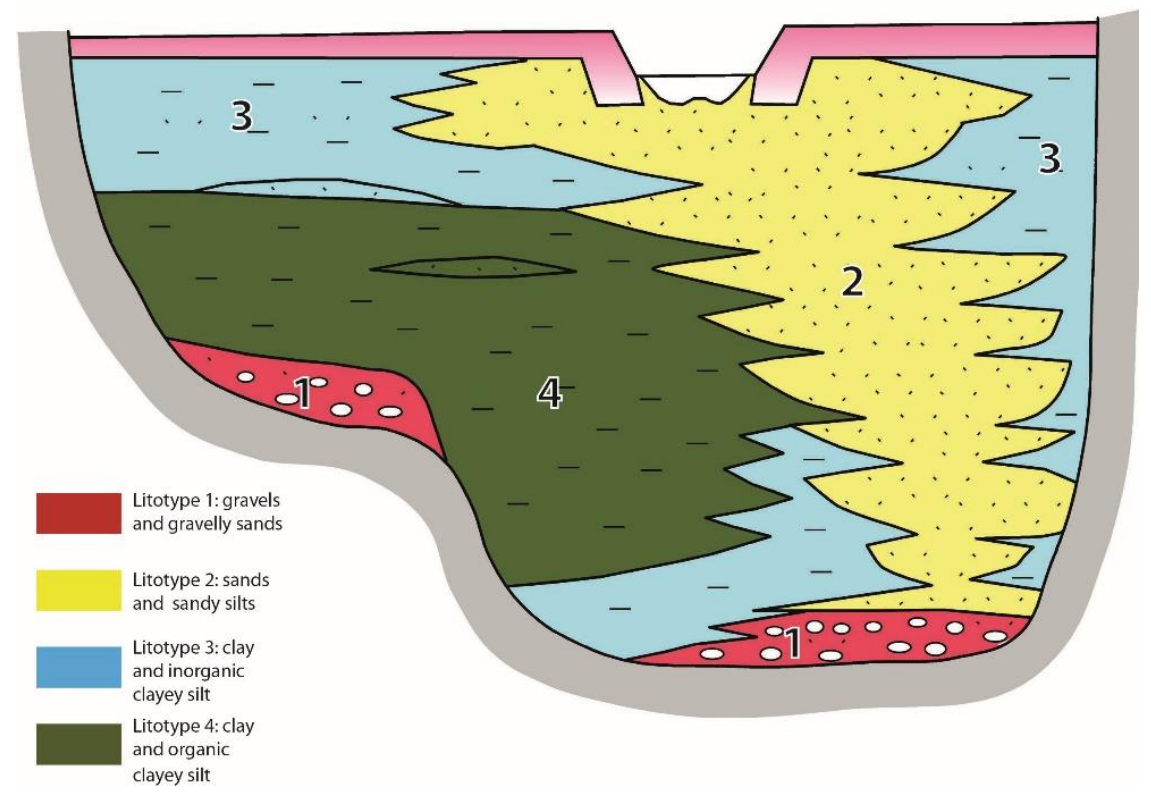

Figure 6: Descriptive section of the distribution of lithotypes in the alluvial body

Table 4: lithotypes and associated codes.

\begin{tabular}{cc}
\hline Lithotype & code \\
\hline Gravels and gravelly sands & 1 \\
Sands and sandy silts & 2 \\
Clay and clayey inorganic silt & 3 \\
Clay and organic clayey silt & 4 \\
\hline
\end{tabular}

\section{Flattening of Bodies}

Geometries of depositional surface of the sedimentary bodies depends on the conditions existing at the moment of deposition, while the current position of the bodies depends on eventual tectonic movements successive to the deposition. Hence, it is not a given that the surface of deposition and the current position coincide. In this study, the surfaces of deposition of the alluvial terrains were correlated parallel to each other and inclined toward the coastline, with the same angle of inclination of the current topographic surface.

If we were to operate a horizontal cut at a given depth in the Tiber River depositional sequence, we would intercept diverse stratigraphic intervals at the same depth, younger toward the valley and older uphill. Therefore, all of the depositional surfaces, as well as the current topographic surface, were rotated so that the horizontal cut lies inside the same isochrone.

This required the definition of the so-called reference level, that is the level of flattening and, if necessary, to re-establish the horizontal continuity of the lithotypes.

Having identified the reference level, the domain of the study was deformed (this operation is known as flattening) through geometric transformations of the coordinates, with return the reference level to a horizontal plane. In this case study, the reference level is essentially linked to the topographic structure of the area: a depositional surface sloping toward the coastline and with a slope equal to the average gradient of the current axis of the river. The geometry of the deposits was restored by transforming the coordinates through an operation of rotation. 


\section{lution}

Mapping of the Diverse Depths of Lithotypes and Definition of the Spatial Reso-

The next step was a mapping at diverse depths, every $5 \mathrm{~m}$, of the recognised lithologies in order to identify in plan the principal associated geomorphological elements and environments (active channel-levee areas, drained and undrained floodplain; figure 7) and reconstruct its areal distribution. This was followed by a process of rasterising the surfaces at a cell resolution of $50 \mathrm{~m}$ (figure 7).

This cell value was determined through a comparison with the average dimensions of the sedimentary bodies to be modelled. In the model to be created, the bodies present an average width of 100-200 m, and therefore the selected resolution was considered suitable to the representation of the different bodies. A lower resolution (and a consequent large cell dimension) would lead to a loss in information.

Each lithotype was associated with a numerical code, in accordance with Table 4.
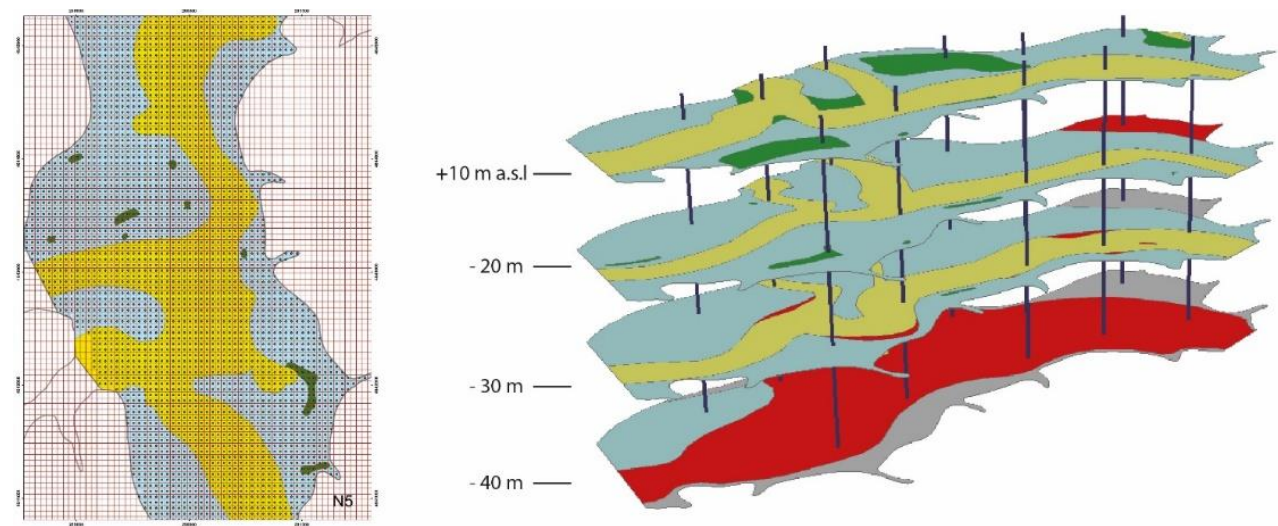

Figure 7: . Rasterization of the model with a cell resolution of $50 \mathrm{~m}$, on the left. On the right, reconstruction of paleoenvironments in the Tiber River valley. Active channel and channel-levee areas (red for gravels, yellow for sands and silty sands) and drained and undrained floodplain (blue for clays, green for peats) are mapped at different depth. In gray the lithotypes of the substrate. Vertical boreholes (black lines) used to constrain the model are also reported.

\subsection{Hydrogeological Monitoring}

For the monitoring of aquifer levels as described, two open standpipe piezometers were installed in boreholes S3 (S3-OS) and S2 (S2-OS) and an electric Vibrating Wire in piezometer S3 (S3-CV). The piezometers consent the monitoring of complexes 4 a (clays), $4 \mathrm{~b}$ (sands) and $4 \mathrm{~d}$ (gravels in a sandy-silty matrix), Table 5.

Table 5: List of piezometer types, monitored complex and depth of the fissured interval or monitoring cell

\begin{tabular}{llll}
\hline Borehole & Piezometer type & $\begin{array}{l}\text { Monitored } \\
\text { complex }\end{array}$ & $\begin{array}{l}\text { Depth of the fissured interval or } \\
\text { monitoring cell (m from ground) }\end{array}$ \\
\hline S3 & Open standpipe - OS & $4 \mathrm{~d}$ & $30-44$ \\
S2 & Open standpipe - OS & $4 \mathrm{~b}$ & $50-58$ \\
S3 & Vibrating Wire - VW & $4 \mathrm{a}$ & 27 \\
\hline
\end{tabular}

Dataloggers for continuous head level monitoring were installed in the open standpipe piezometers. Additionally, manual measurements were taken periodically using a water level meter (phreatimeter). The dataloggers of both the open standpipe piezometers and the electric piezometer were programmed to take hourly measurements.

\subsection{The Numerical Groundwater Model}


The 3D reconstruction of the lithotypes was used to set up a steady state numerical groundwater model with the MODFLOW 2000 code ([28]) and the Groundwater Vistas 6 graphical interface.

The objective of the model was to verify the conceptual model, comparing the values of hydraulic conductivity calibrated with theoretical values.

The model was implemented in the portion with the greatest density of piezometric control points (targets); other than the monitoring piezometers of the present study, they also include the piezometric data collected between 1991-2010, selected and extracted from the UrbiSIT-LINQ database ([29]).

The numerical model area covers a portion of the geological model, for a total area of 6,336,000 $\mathrm{m}^{2}$ (66 rows, 60 columns of dimension 40x40 m2), and was set up with 7 Layers. The initial recharge was assigned uniformly to the domain of the model, considering the average values of effective infiltration in the urban area of Rome $(0.00292 \mathrm{~m} / \mathrm{d}$, [29]). The recharge value as then calibrated.

River boundary conditions (Cauchy type) are used to simulate Tiber River in layer 4; the required input of riverbed hydraulic conductivity was set uniformly equal to $1 \mathrm{~m} /$ day, assuming that this is a reasonable value for sandy-clayey riverbed sediments.

Constant head boundary conditions were set along the eastern boundary in layer 1 , in order to reproduce the observed head field at model boundary.

The initial values of horizontal hydraulic conductivity $(K x=K y)$ were assigned to the lithotypes in accordance with Table 27; the values of vertical conductivity were assigned as $1 / 10$ the value of $\mathrm{Kx}$ and $\mathrm{Ky}$.

The model was calibrated using 86 observation points (targets) using the PEST calibration software.

\section{Results}

\subsection{D Geolithological Model}

The mapping of the lithotypes every 5 metres consents an almost three-dimensional reconstruction of the sedimentary bodies, which can be utilised as an instrument for further geotechnical and hydrogeological analyses. As described in paragraph 3.1, the spatial distribution of the lithotypes with the associated geotechnical (physical-mechanical) and hydrogeological parameters mimics the distribution of lithofacies filling the river valley. This permits the identification of relatively homogenous lithological domains in the subsoil, in terms of associated geotechnical and hydrogeological properties. Regarding the relations between the sedimentary features and hydrogeology, it is well known that the lateral-verticality of the lithofacies and depositional elements in the subsoil can condition hydraulic connectivity in alluvial terrains ([30]; [31]). Therefore, a proper reconstruction of the stratigraphic architecture in alluvial contexts, in particular for incised valleys, is fundamental for the geometric characterisation of aquifers.

The three-dimensional model was therefore created using the software Rockworks produced by Rockware ([32]). Rockworks software algorithms can be used to interpolate continuous stratigraphic surfaces that, when stacked, form a 3D stratigraphic model. Other functions enable the user to create individual logs or multi-log cross sections, fencediagrams and 2D and 3D maps. Furthermore, it provides some GIS processing tools as well as import/export capabilities in various formats ([33]). The resulting model is a numeric file containing a list of points $(X, Y, Z)$ regularly distanced and interpolated based on a value that represents the parameter to be modelled, in the case examined here, the lithology.

The distance between points determines the measure of the "voxel" that, in fact, represents the resolution returned by the model. The size of the voxel or resolution of the model, in general, is calculated automatically by the software based on the distribution of 
the data present in the study area. In the case examined here, as described in paragraph 3.1, the voxels were based on the values of $50 \mathrm{~m}(\mathrm{X}) \times 50 \mathrm{~m}(\mathrm{Y}) \times 5 \mathrm{~m}(\mathrm{Z})$.

The resulting model was successively cut vertically and horizontally to obtain profiles, sections, fence diagrams and slices at different depths. The model of the lithologies was reconstructed utilising the following methodology:

1. rasterization using a $50 \mathrm{~m} \times 50 \mathrm{~m}$ cell of each paleogeographic map;

2. assignment at the centroid of each cell of the corresponding lithology;

3. reconstruction, for each vertical passing through the diverse centroids, of the lithotypes encountered at diverse depths.

This makes it possible for the entire study area to define the lithologies present along a series of horizontal layers, from $15 \mathrm{~m}$ a.s.l. to $-40 \mathrm{~m}$ a.s.l., with $5 \mathrm{~m}$ intervals. The base data are input into the software using Rockworks Project database which requires the mandatory compiling of the following fields: Borehole Name; Easting, Northing; Elevation, TD -Total Depth.

Successively, for each single borehole, it was necessary to compile the Lithology Datasheets Table. This table requires that the following are defined for each lithological horizon in the borehole:

- depth from grade to the top of the layer (Depth to top)

- depth from grade to the bottom of the layer (Depth to Base)

- lithological type (Keyword) connected with the Lithology Types Tables, listing the numerical codes defined for the diverse lithologies to be modelled.

After assigning the codes and patterns to the lithologies, using the "Lithology Model", it was possible to model the geometries of the diverse lithological bodies identified in three dimensions. As an algorithm of interpolation of data, the choice was made to use the Nearest Neighbours method. This method of interpolation makes it possible to assign to the node of each Voxel the value of the closest Voxel. This method has the advantage of honouring the data input into the model, though it has the disadvantage of returning a model of blocks, and thus the lithologies do not present the nuances found in nature, but represents them with brusque interruptions.

Restrictions or constraints were then applied to the model to fix the modelling of the lithologies in space (figure 8). The following constraints were utilised: for the upper surface the base of the backfill was applied, while for the lower surface the cover of the Monte Vaticano Formation was applied (Table 3).

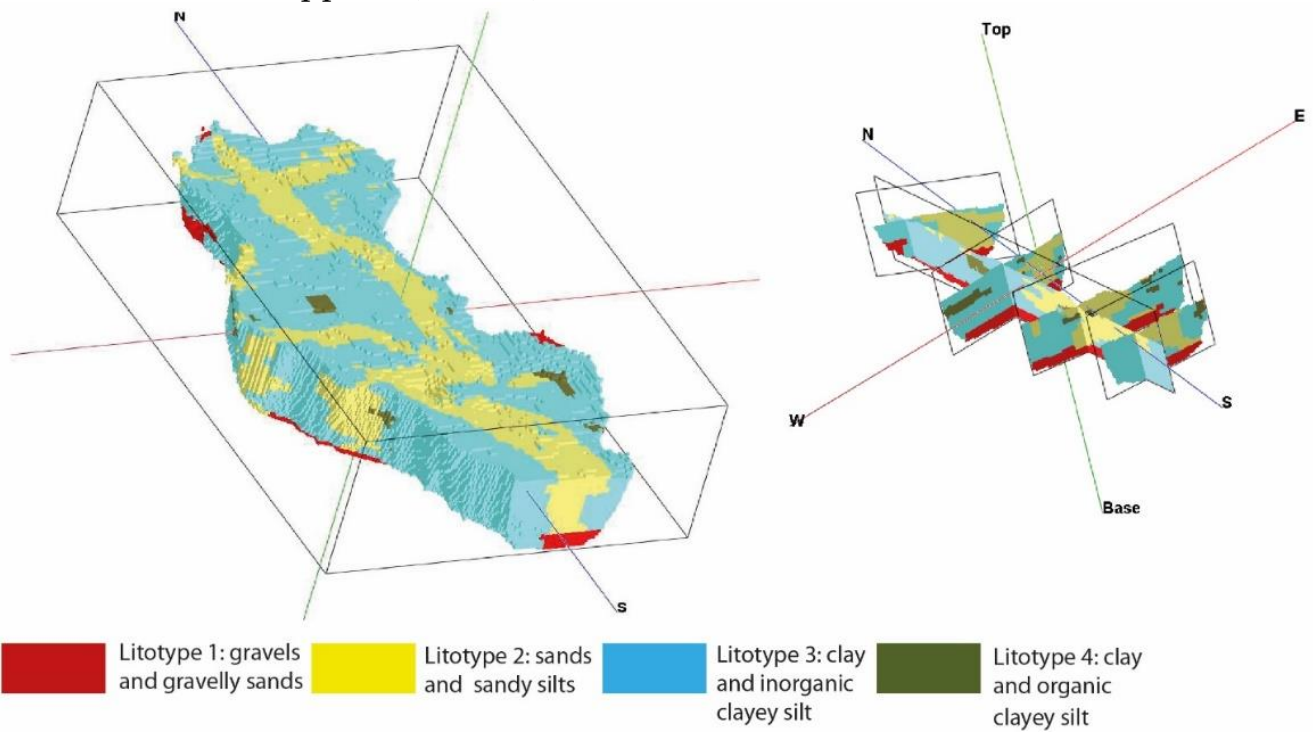

Figure 8: 3D model (left side) of the Tiber River depositional sequence and model cut into cross sections (right side). 
The results demonstrate that the oscillations in the piezometric level of the gravely and sandy lithotypes are strictly dependent on the flow of the river (figures 9 and 10). The level of the Tiber (recorded at the Ripetta station) is subject to oscillations of various periods, including oscillations in tides and flood waves. The oscillations with the shortest period are the result of tide oscillations; a complete tide oscillation in the Mediterranean Sea lasts roughly 12 hours and 25 minutes. As a consequence, over the course of 24 hours there are 2 high points and 2 low points, with oscillations in the order of 0.25 metres and a maximum range of 0.43 metres. The head level in piezometers S2-OS and S3-OS is influenced by both the peaks of fluvial flooding and the oscillations caused by tide cycles. The amplitude of the oscillations is minor with respect to the level of the Tiber. Furthermore, the dampening of the amplitude of the oscillations is greater for S3-OS than for S2-OS. The level in piezometer S2-OS is always greater than the level of the Tiber, except during flooding, when an inversion occurs, and the river passes from gaining to losing.

The level in piezometer S3-OS is on average lower than the level of the Tiber, though in some cases it is greater. The change in levels appears instead to be scarcely influenced by rainfall.

In piezometer S3-VW instead, the brief period oscillations caused by tides were not recognisable, while in those caused by flood peaks there were notably visible.

During the period monitored, the piezometric level appears to have dropped considerably. In particular, from an average of roughly 6.5 metres during the period between October 2014- February 2015, this value moved to an average of 5 metres between February 2015-October 2010, with a constantly decreasing trend. The negative trend corresponds with a diminution in rainfall recorded during the same period.

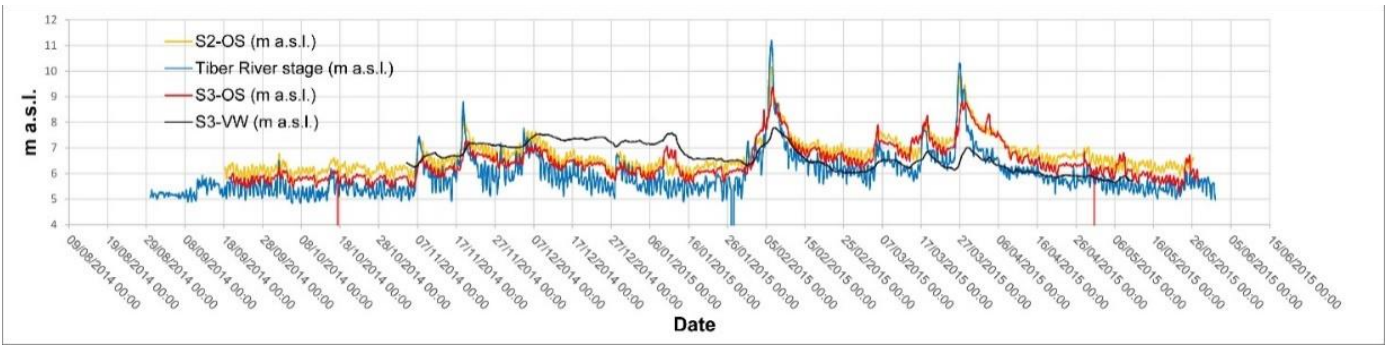

Figure 9: Recorded head level in the 3 piezometers and comparison with the Tiber River. 


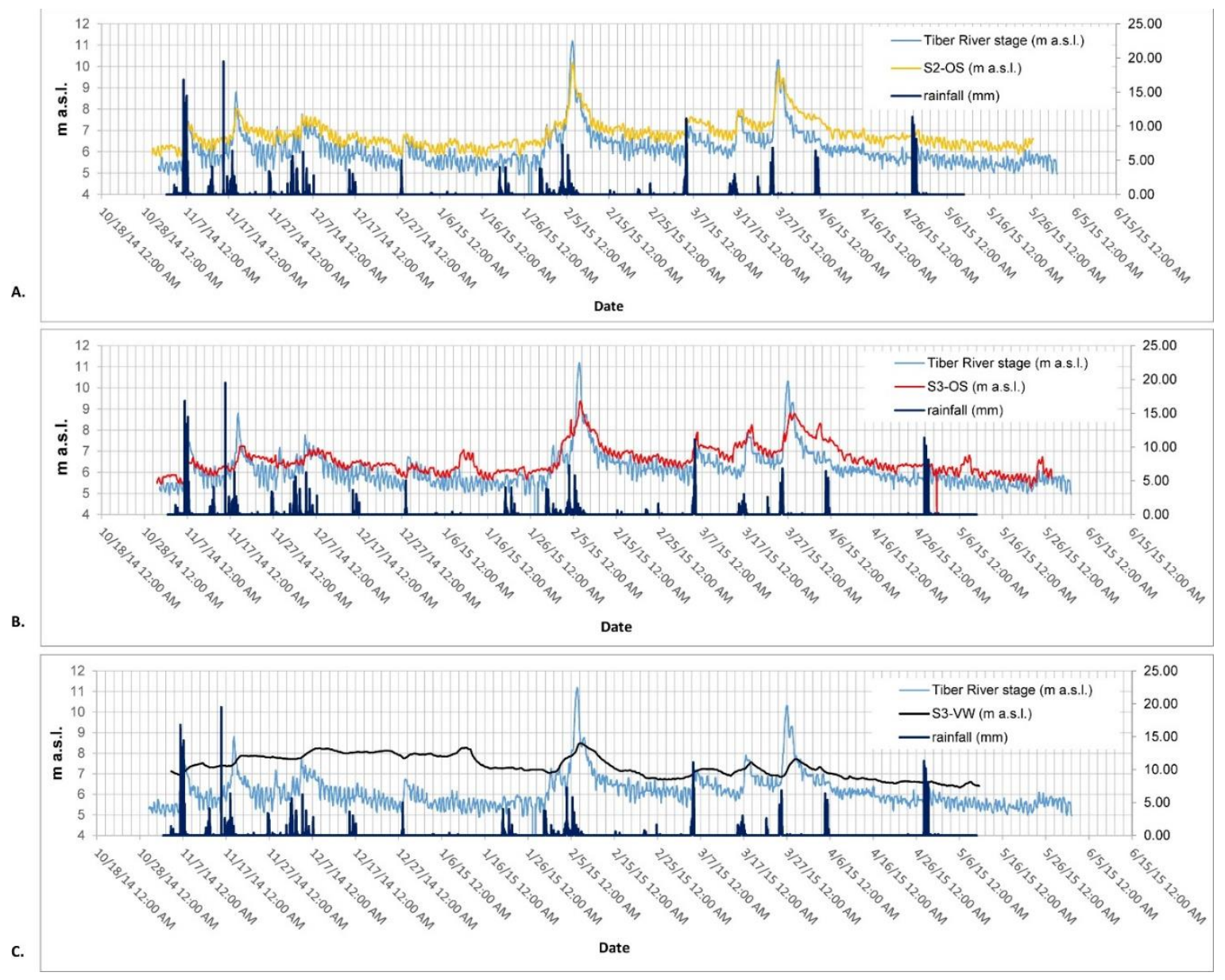

Figure 10: Recorded head level and comparison with rainfall and Tiber stage in Open Standpipe piezometers S2 (A), Open Standpipe S3 (B) and Vibrating wire S3 (C).

\subsection{Numeric Hydrogeological Model}

The results of the statistical calibration of the numeric model are summarised in Table 6 and Figure 11.

The process of calibration produced an estimate of the optimum value of hydraulic conductivity in correspondence with the model targets; the estimated values of $\mathrm{k}$ were then interpolated, for each layer, by the software using Ordinary Kriging (Fig. 12). In addition to the values of $k$, recharging was also calculated, arriving an optimum value of $0.00068 \mathrm{~m} / \mathrm{d}$.

Table 6: Statistical parameters of the calibrated model

\begin{tabular}{cc}
\hline Statistical Parameter & Value \\
\hline Number of head observations & 86 \\
Residual Mean & -0.23 \\
Residual Standard Deviation & 1.39 \\
Absolute Residual Mean & 1.06 \\
Residual Sum of Squares & 170 \\
RMS Error & 1.41 \\
Minimum Residual & -3.81 \\
Maximum Residual & 2.86 \\
\hline
\end{tabular}




\section{Observed vs. Computed Target Values}

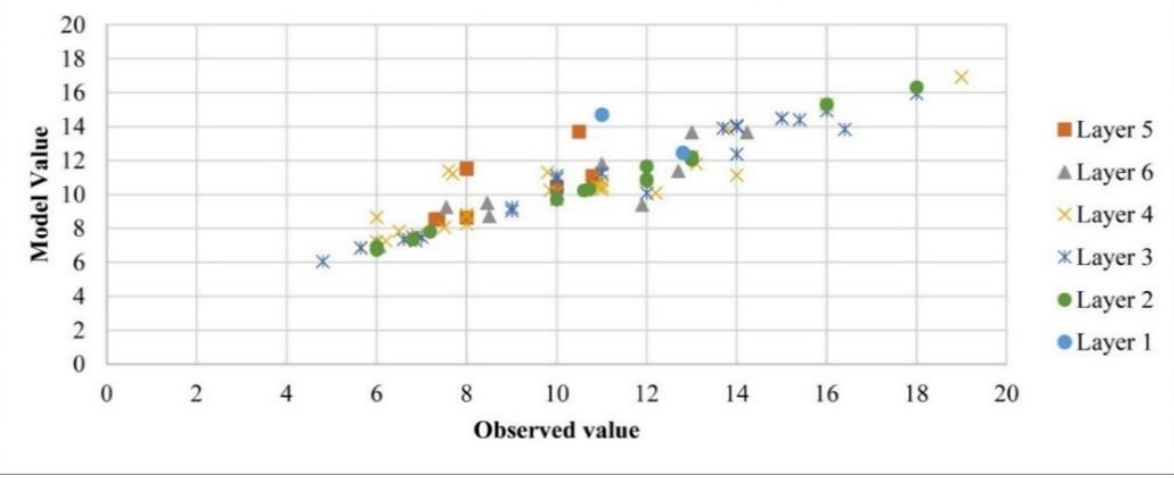

Figure 11: Scatterplot of observed versus computed target values.

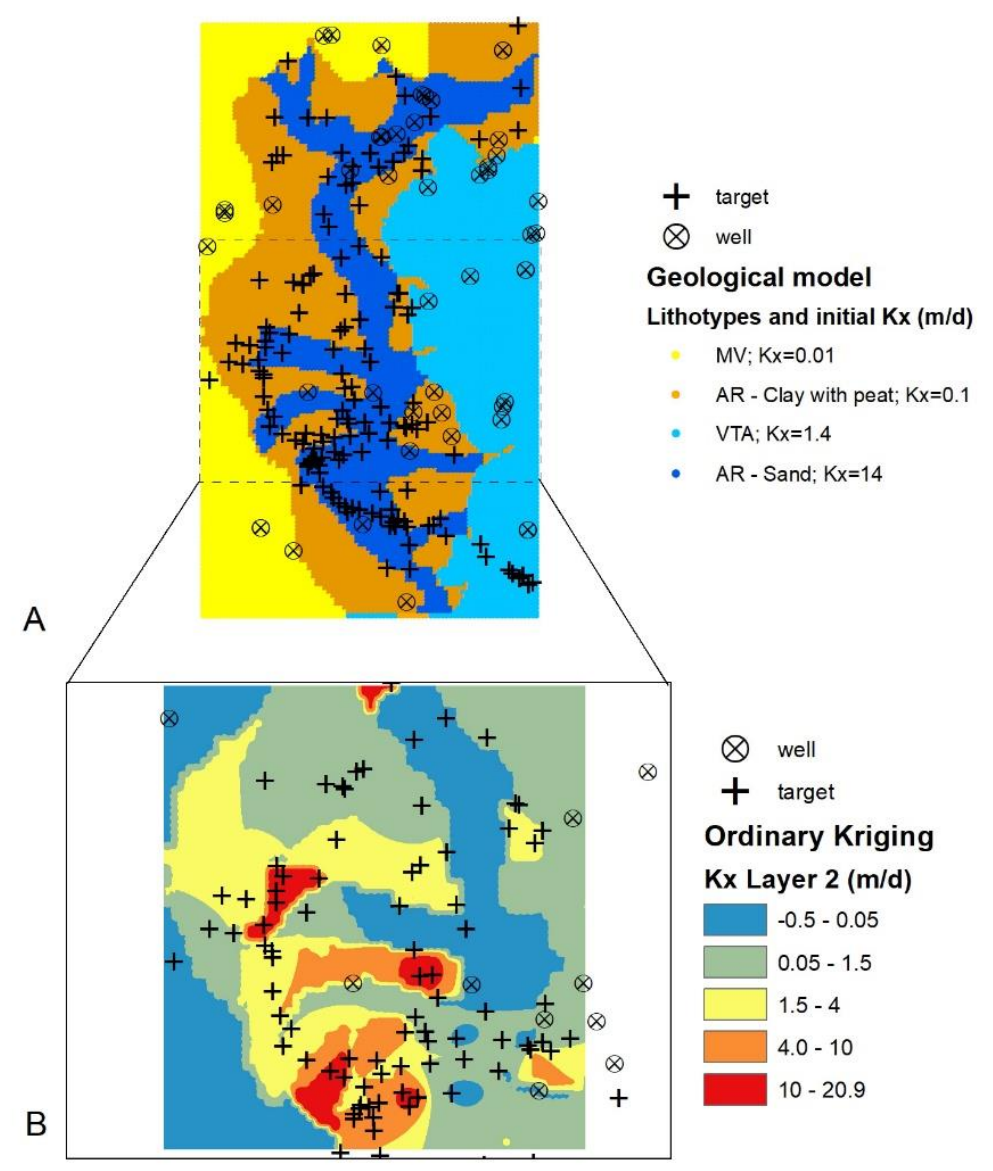

Figure 12: A. Geological model from 5 to -5 meters a.s.l.: colours represent the horizontal hydraulic conductivity $(\mathrm{Kx})$ initially assigned to lithotypes. B: Numerical groundwater model, Layer 2: colours represent the hydraulic conductivity values after sensitivity analysis and calibration.

\section{Discussions}


The results of the monitoring shed light on the diverse hydrogeological behaviour of the lithotypes as a function of the oscillations of the Tiber River. Despite being a considerable distance from the coastline (Table 1), the flow of the river is strongly influenced by tide oscillations; these oscillations can also be seen in the piezometric head level recorded in the gravely and sandy lithotypes. This data suggests the existence of a strong hydraulic connection between the aquifer hosted in both the base sands and gravels (piezometers S3-OS and S2-OS), and the river, in accordance with the geological structure reconstructed in the three-dimensional model of the lithotypes. The oscillations in the level of the clayey lithotypes (piezometer S3-VW) appear to follow the level of the river during flood events in a more dampened manner with respect to the other piezometers; what is more, no tide oscillations are recognisable; this suggests that this type of lithotype has a scarce connection with the river and a higher storage coefficient, with respect to sandy and gravely lithotypes, in accordance with the data in literature describing the behaviour of alluvial terrains. Finally, the oscillations in the level of piezometer S3-OS demonstrate that the exchange between the river and the water body of the base gravels is subject to inversions in direction based on the height of the fluvial stage: the gravely body can alternately receive water from the river or feed the river.

The results of the calibration of the numeric model show a good correspondence between the head level observed and that simulated. All the same, the kriging mapping of the values of hydraulic conductivity resulting from the calibration of the model differs from the spatial reconstruction of the lithotypes based on the codification of the borehole lithofacies. This suggests that within the principal sedimentary facies recognised and mapped, there is a variability that is not reproduced in the geological model, which needs to the object of further investigations. For example, the distribution of the lithotypes can be mapped beginning with the borehole data using stochastic statistic models. A greater accuracy in the spatial distribution of lithotypes (and therefore a greater accuracy of the conceptual model) may be of fundamental importance for converting the current numeric hydrogeological model into a transitory model. The simulation in a transitory regime would consent the reproduction of the movement over time of the piezometric levels, also under conditions of flooding. Given the strict hydraulic relation between the complex of alluvial deposits and the Tiber River, it is nonetheless necessary to provide a robust geological model, to correctly simulate the response of the system to such stresses as flooding or intense rainfall. As a consequence, the stationary numeric model implemented in this study was useful for understanding how another conceptual model, based on a different distribution of lithotypes, could increase the accuracy of the simulation at the site specific scale and in a transitory regime.

In general, this study demonstrates the importance of structuring an iterative process for the construction of geological and hydrogeological models. In fact, the analysis of the lithofacies and corresponding lithotypes (phases 1 to 3, figure 13) was used to create a 3D lithotype model, which, on turn, was described in hydrostratigraphic terms (phase 6) and was the subject of piezometric levels monitoring (phase 7). Then, the hydrostratigraphic model provided he base for a numerical groundwater model. Nonetheless, the hydrogeological model calibrated using data relative to the aquifer levels in a well suggested further methods for reconstructing sedimentary bodies that provide a better match with observed piezometric head levels (figure 13). In this case, the numeric model in turn supported the refining of the geological model. A geological model opportunely reviewed based on the results of the numeric model may in turn provide the base for hydrogeological modelling in a transitory regime at the site specific scale. Finally, a detailed geological model can also provide the base for other types of numeric models (e.g., differential settlement, subsidence, saline intrusion). The iterative modelling process is thus very important when wishing to proceed with a detailed investigation of such aspects as geohazards, strictly dependent on the distribution of the lithotypes and hydrogeological behaviour. 


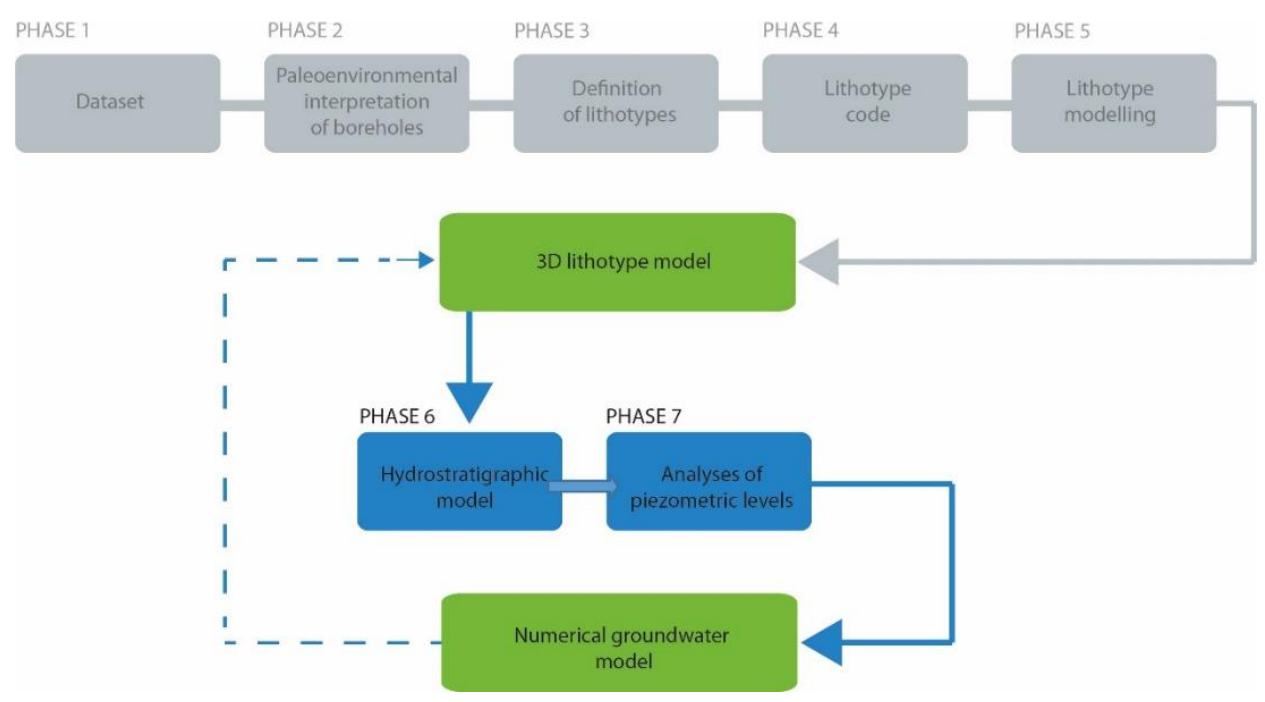

Figure 13: Flowchart showing the iterative process described in this study. The 3D lithotype model and the Numerical groundwater model constitute the main outputs.

Author Contributions: Conceptualization, C.D.S, Ma.Ma; methodology, C.D.S., Ma.Ma, F.S.; Geological modelling software, F.S. Ma.Ma.; Groundwater modelling software, C.D.S., M.D.; validation, C.D.S., F.S.; formal analysis, Ma.Ma., C.D.S.; investigation, C.D.S, Ma.Ma., Ma.Mo.; resources, C.D.S., F.S., M.S., G.P.C.; data curation, F.S., C.D.S., G.P.C.; writing-original draft preparation, C.D.S, Ma.Ma.; writing - review and editing, C.D.S., Ma.Ma, F.S., Ma.Mo., M.S.; visualization, F.S., C.D.S., Ma.Ma; supervision, G.P.C.; project administration, F.S.; funding acquisition, F.S. All authors have read and agreed to the published version of the manuscript.

Funding: Please add: This research was funded by Regione Lazio, FILAS project F87112000080007 “TIBER - Innovazione nel campo geotecnico per la definizione di strumenti, metodologie operative e procedure finalizzate alla realizzazione di un nuovo modello di sottosuolo (modello integrato)" project leader Francesco Stigliano.

Acknowledgments: The authors would like to thank Francesco Versino and Stefano Mastrototaro for their precious technical support during the field surveys. The 3D model and the cartographic elaborations were developed by the GIS Lab (CNR-IGAG; https://www.igag.cnr.it/lista-laboratori/labgis/); the hydrogeological elaborations were developed by the Laboratorio di idrogeologia quantitativa e modellazione numerica (CNR-IGAG; https://www.igag.cnr.it/lista-laboratori/laboratorio-di-idrogeologia-quantitativa-e-modellazione-numerica/).

Conflicts of Interest: The authors declare no conflict of interest.

\section{References}

1. Mancini, M., Girotti, O., Cavinato, G.P. Il Pliocene e il Quaternario della Media Valle del Tevere (Appennino Centrale), Geologica Romana 2004, 37 (2003-2004), 175-236.

2. Mancini, M., Cavinato, G.P. The Middle Valley of the Tiber River, central Italy: Plio-Pleistocene fluvial and coastal sedimentation, extensional tectonics and volcanism. In Fluvial Sedimentology VII, IAS (International Association of Sedimentologists) Special Publication; Blum M., Marriot S., Leclair, S., Eds., 2005; Volume 35, pp. 373-396.

3. Milli, S., Moscatelli, M., Palombo, M.R., Parlagreco, L., Paciucci, M. Incised-valleys, their filling and mammal fossil record: a case study from Middle-Upper Pleistocene deposits of the Roman Basin (Latium, Italy), GeoActa, 2008, Special Publication: 1, 6788.

4. Milli, S., Mancini, M., Moscatelli, M., Stigliano, F., Marini, M., Cavinato, G.P. From river to shelf, anatomy of a high-frequency depositional sequence: The Late Pleistocene to Holocene Tiber depositional sequence, Sedimentology 2016, 63, 1886-1928 doi: 10.1111/sed.12277

5. Mancini, M., Moscatelli, M., Stigliano, F., Cavinato, G.P., Marini, M., Pagliaroli, A., Simionato, M. Fluvial facies and stratigraphic architecture of Middle Pleistocene incised valleys from the subsoil of Rome (Italy), Journal of Mediterranean Earth Sciences, 2013, Special Issue 2013, 89-93 
6. Schumm, S.A. River Response to Baselevel Change: Implications for Sequence Stratigraphy, The Journal of Geology 1993, 101, 279-294.

7. Gibling, M.R. Width and thickness of fluvial channel bodies and valley fills in the geological record: a literature compilation and classification, Journal of Sedimentary Research 2006, 76, 731-770.

8. Mancini, M., Moscatelli, M., Stigliano, F., Cavinato, G.P., Milli, S., Pagliaroli, A., Simionato, M., Brancaleoni, R., Cipolloni, I., Coen, G., Di Salvo, C., Garbin, F., Lanzo, G., Napoleoni, Q., Scarapazzi, M., Storoni, Ridolfi, S., Vallone, R. The Upper Pleistocene-Holocene fluvial deposits of the Tiber River in Rome (Italy): lithofacies, geometries, stacking pattern and chronology, Journal of Mediterranean Earth Sciences 2013, Special Issue, 95-101.

9. Amorosi, A. Reading late Quaternary stratigraphy from cores: a practical approach to facies interpretation. GeoActa 2006, 5, 6178.

10. Bridge, J.S., Tye, R. S. Interpreting the dimensions of ancient fluvial channel bars, channels, and channel belts from wirelinelogs and cores, American Association of Petroleum Geologists Bulletin, 2000, 84, 1205-1228.

11. Wright, V.P., Marriott, S.B. The sequence stratigraphy of fluvial depositional systems: the role of floodplain sediment storage, Sedimentary Geology, 1993, 86, 203-210.

12. Shanley, K.W., McCabe, P.J. Perspectives on the sequence stratigraphy of continental strata. American Association of Petroleum, Geologists Bulletin, 1994, 78, 544-568.

13. Blum, M.D., Tornqvist, T.E. Fluvial responses to climate and sea-level change: a review and look forward. Sedimentology, 2000, 47, 2-48.

14. Catuneanu, O. Principles of Sequence Stratigraphy; Elsevier, 2006; pp 375.

15. Blum M., Martin J., Milliken K., Garvin M. Paleovalley systems: Insights form Quaternary analogs and experiments, EarthScience Reviews, 2013, 116, 128-169.

16. Milli S., D’Ambrogi C., Bellotti P., Calderoni G., Carboni M.G., Celant A., Di Bella L., Di Rita F., Frezza V., Magri D., Pichezzi R.M., Ricci V. The transition from wavedominated estuary to wave-dominated delta: The Late Quaternary stratigraphic architecture of Tiber River deltaic succession (Italy). Sedimentary Geology, 2013, 284-285, 159-180.

17. Marra, F., Rosa, C. Stratigrafia e assetto geologico dell'area romana (Stratigraphy and geological setting of Rome). In: Mem Desc della Carta Geologica d'Italia. La geologia di Roma. Il centro storico. Funiciello, R., Eds.; 1995, 5, 49-118.

18. Marra, F., Rosa, C., De Rita, D., Funiciello, R. Stratigraphic and tectonic features of the Middle Pleistocene sedimentary and volcanic deposits in the area of Rome (Italy). Quat Intern, 1998, 47/48, 51-63.

19. Funiciello, R., Giordano, G. 2008. Note illustrative della Carta Geologica d'Italia alla scala 1:50.000, Foglio 347 ROMA. APATServizio Geologico d'Italia, Roma, p. 158.

20. Funiciello, R., Praturlon, A., Giordano, G. Memorie Descrittive della Carta Geol. d'Italia. La Geologia di Roma, dal centro storico alla periferia, Part I-II, Vol LXXX, S.E.L.C.A, Firenze. 2008.

21. Marra, F., Carboni, M.G., Di Bella, L., Faccenna, C., Funiciello, R., Rosa, C. Il substrato pliopleistocenico nell'area romana, Boll. Soc. Geol. It. 1995, 114, 195-214.

22. Capelli, G., Mazza, R., Taviani, S., Acque sotterranee nella città di Roma. In La Geologia di Roma - dal centro storico alla periferia. Mem. Descr. Carta Geol. d'It., Funiciello, R., Praturlon, A., Giordano, G., Eds; S.E.L.C.A: Firenze, Italy, 2008; Volume 80, pp. 221245.

23. Lanzini, M. Indagine geognostica per il progetto della linea C della Metropolitana di Roma-Tratta da S. Giovanni a Alessandrino, 1995-1996 technical report, 1995-2000a.

24. Lanzini, M. Indagine geognostica per il progetto della linea C della Metropolitana di Roma-Tratta in variante da Piazza Risorgimento a Piazza Venezia, technical report, 1995-2000b.

25. Di Salvo, C., Di Luzio, E., Mancini, M., Moscatelli, M., Capelli, G., Cavinato, G.P., Mazza, R. GIS-based hydrogeological modeling in the city of Rome: analysis of the geometric the confining hydrogeological complexes, Hydrogeology Journal 2012, 20, 1549-1567.

26. La Vigna, F., Demiray, Z. \& Mazza, R., Exploring the use of alternative groundwater models to understand the hydrogeological flow processes in an alluvial context (Tiber River, Rome, Italy), Environ Earth Sci 2014, 71, 1115-1121. https://doi.org/10.1007/s12665-013-2515-8.

27. La Vigna, F., Mazza, R., Amanti, M., Di Salvo, C., Petitta, M., Pizzino, L., Pietrosante, A., Martarelli, L., Bonfà, I., Capelli, G., Cinti, D., Ciotoli, F., Ciotoli, G., Conte, G., Del Bon, A., Dimasi, M., Falcetti, S., Gafà, R. M., Lacchini, A., Mancini, M., Martelli, S., Mastrorillo, L., Monti, G.M., Procesi, M., Roma, M., Sciarra, A., Silvi, A., Stigliano, F., and Succhiarelli, C. Groundwater of Rome, Journal of Maps 2016, 12, sup1, 88-93, DOI: 10.1080/17445647.2016.1158669.

28. Harbaugh, A.W., Banta, E.R., Hill, M.C., McDonald, M.G. MODFLOW-2000, the U.S. Geological Survey modular ground-water model-user guide to modularization concepts and the groundwater flow process, USGS Open-File Report 00-92; U.S. Geological Survey: Reston, Virginia, 2000.

29. Di Salvo, C., Moscatelli, M., Mazza, R., Capelli, G., Cavinato, G.P., Evaluating groundwater resources of an urban alluvial area through the development of a numerical model. Environ Earth Sci, 2014, 72, 2279-2299.

30. Huggenberger, P., Regli, C. A sedimentological model to characterize braided river deposits for hydrogeological applications. In Braided Rivers: Process, Deposits, Ecology and Management; Sambrok Smith, G.H., Best, J.L., Bristow, C.S., Petts, G.E., Eds.; IAS (International Association of Sedimentologists) Special Publication, 36, 2006, pp. 51-74. 
31. Valloni, R., Calda, N. 2007. Late Quaternary Fluvial Sediment Architecture and Aquifer Systems of the Southern Margin of the Po River Plain. In Sviluppo degli studi in sedimentologia degli acquiferi ed acque sotterranee. Mem. Descr. Carta Geol. d'It., Valloni, R., Eds; S.E.L.C.A: Firenze, Italy, 2007; Volume 76, pp. 289-300.

32. Rockworks, Rockware, Inc. Available online: at: www.rockware.com. (Accessed on 18 May 2017).

33. Velasco, V., Gogu, R., Alcaraz, M., The use of GIS-based 3D geological tools to improve hydrogeological models of sedimentary media in an urban environment, Environmental Earth Sciences, 2013, 68, 2145-2162. 